Jurnal Penelitian Pendidikan Geografi Volume 4 Nomor 1 Januari 2019

\title{
PERSEPSI MASYARAKAT TENTANG DAMPAK PENAMBANGAN NIKEL TERHADAP LINGKUNGAN FISIK DI DESA MONDOE KECAMATAN PALANGGA SELATAN KABUPATEN KONAWE SELATAN
}

\author{
Elsah Bonita Iman Sari ${ }^{1}$ \\ ${ }^{1}$ Email : elsahbonitaimansari96@gmail.com
}

${ }^{1}$ Alumni Jurusan Pendidikan Geografi FKIP UHO

\begin{abstract}
Abstrak :Rumusan masalah dalam penelitian ini (1) Bagaimanakah pandangan masyarakat tentang penambangan nikel terhadap dampak lingkungan di Desa Mondoe Kecamatan Palangga Selatan? (2) Bagaimanakah dampak penambangan nikel terhadap lingkungan yang terjadi di Desa Mondoe Kecamatan Palangga Selatan? (3) Upaya apa yang dilakukan masyarakat dan pemerintah dalam mengatasi dampak lingkungan terhadap penambangan nikel yang terjadi di Desa Mondoe Kecamatan Palangga Selatan?. Penelitian ini menggunakan metode penelitian deskriptif kualitatif dengan pendekatan mix metode. Hasil yang diperoleh dalam penelitian ini dapat dikemukakan sebagai berikut (1) Penelitian menggambarkan bahwa pandangan masyarakat Desa Mondoe terhadap keberadaan perusahaan pertambangan di wilayah Desa Mondoe merusak lingkungan (2) Bentuk-bentuk kerusakan lingkungan fisik akibat pertambangan nikel yaitu kerusakan lahan hutan, tejadinya tanah longsor, jalan raya rusak bertambahnya lahan kritis, kerusakan lahan, peningkatan polusi udara dan pencemaran air bersih (3) Upaya yang dilakukan perusahan, pemerintah dan masyarakat dalam meminimalisir dampak negatif pertambangan yaitu rehabilitasi lahan bekas penambangan, penyiraman air untuk mengurangi polusi debu secara berkala dan perbaikan jalan raya yang rusak.
\end{abstract}

Kata Kunci : Proses aktivitas perusahaan tambang, kerusakan lingkungan, masyarakat Desa Mondoe 
Jurnal Penelitian Pendidikan Geografi Volume 4 Nomor 1 Januari 2019

\title{
THE PERCEPTION OF THE COMMUNITY ABOUT IMPACT OF NICKEL MINING FOR PHYSICAL ENVIRONMENT IN MONDOE VILLAGE SOUTH PALANGGA DISTRICT SOUTH KONAWE REGENCY
}

\author{
Elsah Bonita Iman Sari ${ }^{1}$ \\ ${ }^{1}$ Email : elsahbonitaimansari96@gmail.com
}

${ }^{1}$ Alumni Of Geography Education FKIP UHO

\begin{abstract}
Problem formulation of this research are (1) How did the views of the public about the nickel mining against environmental impact in the village of the subdistrict Mondoe Palangga South? (2) How does the impact of nickel mining on the environment which took place in the village of the subdistrict Mondoe Palangga South? (3) What Efforts the society and Government in addressing environmental impacts against the mining of nickel which occurred in the village of the subdistrict Mondoe Palangga South?. This research uses qualitative research methods, descriptive approach to the mix of methods. The results obtained in this study can be expressed as follows (1) The research illustrates that the villagers view Mondoe against the existence of mining companies in the region of the village of environmentally destructive Mondoe (2) Forms physical damage to the environment resulting from the mining of nickel, namely damage to woodlands, the occurrence of landslides damaged roadways, the increase of critical land, destruction of land, increasing air pollution and water pollution clean (3) Efforts made the company, the Government and the community in to minimize the negative impact of mining land rehabilitation of former mining activities, namely, watering water to reduce pollution dust regularly and repair damaged highways.
\end{abstract}

Keywords :Process of the activity of the company mines, environmental damage, the villagers Mondoe

\section{PENDAHULUAN}

Indonesia merupakan negara yang kaya akan potensi sumberdaya alam yang sangat berlimpah, potensi ini merupakan modal berharga bagi pembangunan nasional yang harus dikelola dan dimanfaatkan secara baik dan optimal sehingga diharapkan dapat memberikan kemakmuran dan kesejahteraan bagi seluruh rakyat Indonesia.Sumber daya alam itu sendiri tersebar di beberapa wilayah yang ada di Indonesia termasuk sumber daya alam nikel

\begin{abstract}
yang terdapat di Sulawesi Tenggara tepatnya di Desa Mondoe Kecamatan Palangga Selatan Kabupaten Konawe Selatan.
\end{abstract}

Sulawesi Tenggara sebagai salah satu provinsi yang memiliki sumber daya alam nikel yang cukup banyak untuk dikelola harusnya menjadi lebih maju apabila sumber daya alam itu dikelola dengan baik. Berlakunya Undang-Undang Nomor 32 Tahun 2004 tentang Pemerintahan Daerah, memberikan 
kewenangan pengelolaan sumber daya alam khususnya pertambangan kepada masingmasing daerah. Kewenangan untuk pengelolaan pertambangan dari tingkat pusat hingga kabupaten/kota telah diatur pula dalam Undang-Undang Nomor 4 Tahun 2009 tentang Pertambangan Mineral dan Batubara.

Lahirnya kedua peraturan tersebut diats seharusnya semakin memperkuat posisi pemerintah daerah dalam hal ini pemerintah tingkat Kabupaten/Kota untuk mengatur dan mengelola sumber daya alam khusunya nikel untuk mendatangkan manfaat yang sebesar besarnya untuk masyarakat.Faktanya sangat disayangkan pemerintah Kabupaten/Kota belum memaksimalkan kekuatan hukum ini dalam penegakan upaya pengelolaan pertambangan yang ramah lingkungan dan bermanfaat besar bagi masyarakat.

Secara teoritis menurut Elsam (2003), menyatakan bahwa kehadiran perusahaan pertambangan di suatu daerah niscaya membawa kemajuan terhadap warga di sekitarnya. Berdiri atau beroperasinya sebuah pertambangan di suatu daerah akan menghadirkan kehidupan yang lebih sejahtera, keamanan yang terjamin, dan kehidupan sosial yang lebih baik termasuk peningkatan kehidupan ekonomi masyarakat terutama daerah yang berhubungan langsung dengan tempat pengolahan sumber daya alam.

Pemikiran diatas
didasarkan pada pandangan bahwa perusahaan pertambangan merupakan agen perubahan sosial-ekonomi bagi masyarakat di sekitar lokasi pertambangan. Asumsinya, perusahaan pertambangan akan membawa serta arus investasi, membongkar isolasi warga, dan membuka akses masyarakat terhadap dunia luar. Secara praktis kehadiran perusahaan pertambangan diharapkan akan dibangun berbagai infrastruktur yang diperlukan masyarakat, seperti jalan, aliran listrik, air bersih, transportasi, dan jaringan komunikasi. Asumsi seperti yang diuraikan di atas, saat ini tidak selalu berjalan sesuai dengan harapan.

Persepsi (dari bahasa Latin percepti $o$, percipio) adalah tindakan menyusun, mengenali, dan menafsirkan informasi sensoris guna memeberikan gambaran dan pemahaman tentang lingkungan. Persepsi meliputi semua sinyal dalam sistem saraf, yang merupakan hasil dari stimulasi fisik atau kimia dari organ pengindra.Seperti misalnya penglihatan yang merupakan cahaya yang mengenai retina pada mata, pencium yang memakai media molekul bau (aroma), dan pendengaran yang melibatkan gelombang suara.

Menurut (Bimo Walgito, 2003:3). Persepsi merupakan proses yang didahului oleh proses pengindraan, yaitu merupakan proses diterimanya stimulus oleh individu melalui alat indera atau disebut juga proses sensoris. Sedangkan Sarlito Wirawan Sarwono, 2000:60 mengungkapakan dalam bukunya "Psikologi Lingkungan" mengatakan bahwa persepsi adalah jika jumlah pengindraan disatukan dan dikoordinasikan di dalam pusat syaraf yang lebih tinggi (otak) sehingga manusia dapat mengenali dan menilai objek-objek.

Berdasarkan observasi awal yang dilakukan pada tanggal 25 Januari 2018 menemukan berbagai fakta diantaranya seperti halnya air bersih, masyarakat justru akan semakin mengalami krisis air bersih dalam waktu sekarang maupun masa yang akan datang karena eksploitasi yang dilakukan perusahan terhadap hutan dan juga alam akan semakin mempengaruhi ketersediaan air tanah, harapan lain masyarakat seperti jalan dan transporatasi juga belum terakomodasi, jalan raya justru menimbulkan polusi yang terusberdampak pada lingkungan dan masyarakat di sekitar area pertambangan. Kebutuhan masyarakat 
dengan layanan transportasi umum pun juga belum dapat terpenuhi karena transportasi yang disediakan oleh perusahan hanya diperuntukan untuk kepentingan perusahaan dan karyawanya.

Aspek ekonomi dengan adanya kegiatan pertambangan harusnya mampu mendatangkan keuntungan yang sangat besar yaitu mendatangkan devisa dan menyerap tenaga kerja sangat banyak bagi daerah Kabupaten/Kota untuk bisa meningkatkan Pendapatan Asli Daerah (PAD) dengan kewajiban pengusaha membayar retribusi dan lain-lain. keuntungan ekonomi yang diharapkan seperti diuraikan diatas juga belum mampu didapat oleh masyarakat di Desa Mondoe Kecamatan Palangga Selatan Kabupaten Konawe Selatan. Tinjauan lebih lanjut menemukan bahwa selain masalah belum terpenuhinya peningkatan ekonomi masyarakat masalah lain yang tidak kalah penting yaitu dari kegiatan penambangan yang dialakukan justru tidak sebanding dengan kerusakan lingkungan akibat kegiatan penambangan yang syarat dengan eksplorasi dan eksploitasi sumber daya alam.Berdasarkan uraian permasalahan diatas maka menarik bagi peneliti untuk melakukan kajian secara mendalam secara ilmiah dan empirik melalui penelitian ini untuk mengetahi lebih jauh tentang masalah yang diuraikan diatas dengan tema penelitian "Persepsi Masyarakat Tentang Dampak PenambanganNikel Terhadap LingkunganFisik Di Desa Mondoe Kecamatan Palangga Selatan Kabupaten Konawe Selatan".

\section{METODE PENELITIAN}

Penelitian ini akan dilaksanakan di Desa Mondoe Kecamatan Palangga Selatan Kabupaten Konawe Selatan. Penentuan lokasi penelitian ini didasarkan pada pertimbangan bahwa di Desa Mondoe Kecamatan Palangga Selatan Kabupaten Konawe Selatan adalah salah satu wilayah yang berhubungan langsung dengan area pertambangan nikel.Dengan kondisi ini maka potensi dampak dari penambangan nikel terhadap lingkungan dan masyarakat sekitar sangat besar, maka sangat memungkinkan menimbulkan presepsi masyarakat terhadap masalah pertambangan yang dilakukan di daerah ini. Penelitian ini akan dilaksanakan pada tanggal 1 April sampai Mei 2018.

Jenis penelitian yang dilakukan oleh penulis adalah lapangan(field research) dengan menggunakan metode penelitian mix metode. Menurut Craswell 2010:5, penelitian campuran (mix methods) adalah merupakan pendekatan penelitian dengan mengkombinasi antara dua metode penelitian kualitatif dan metode kuantitatif. Sedangkan menurut Sugiyono (2011:404) bahwa, Metode penelitian kombinasi (mixed methods) adalah suatu metode penelitian yang mengkombinasikan atau menggabungkan antara metode kuantitatif dan metode kualitatif untuk digunakan secara bersama-sama dalam suatu kegiatan penelitian sehingga diperoleh data yang lebih komprehensif, valid, reliabel dan objektif.

Responden dalam penelitian ini adalah masyarakat di Desa Mondoe Kecamatan Palangga Selatan yang berjumlah 30 orang yang diambil dengan cara menggunakan proposive sampling atau dengan cara penunjukan. Selain responden peneliti juga menggunakan Informan penelitian berjumlah 4 orang, yaitu 1 orang Kepala Desa Mondoe, Sekdes Mondoe, Ketua Karang Taruna dan Ketua BPD Desa Mondoe.

Teknik yang digunakan dalam pengumpulan data dalam penelitian ini terbagi tiga yaitu observasi, wawancara dan dokumentasi. 
Dalam penelitian ini, teknik analisis data yang digunakan ialah dengan menggunakan Mix Metode (Desain Kombinasi.Menurut sugionao 2011:404) desain kombinasi adalah penggabungan dua metode yaitu kualitatif dan kuantitatif yang digunakan secara bersama-sama dalam suatu kegiatan penelitian.Dalam analisis data yang akan dilakukan oleh penulis untuk lebih jelasnya dapat dilihat dalam bentuk gambar diagram berikut.

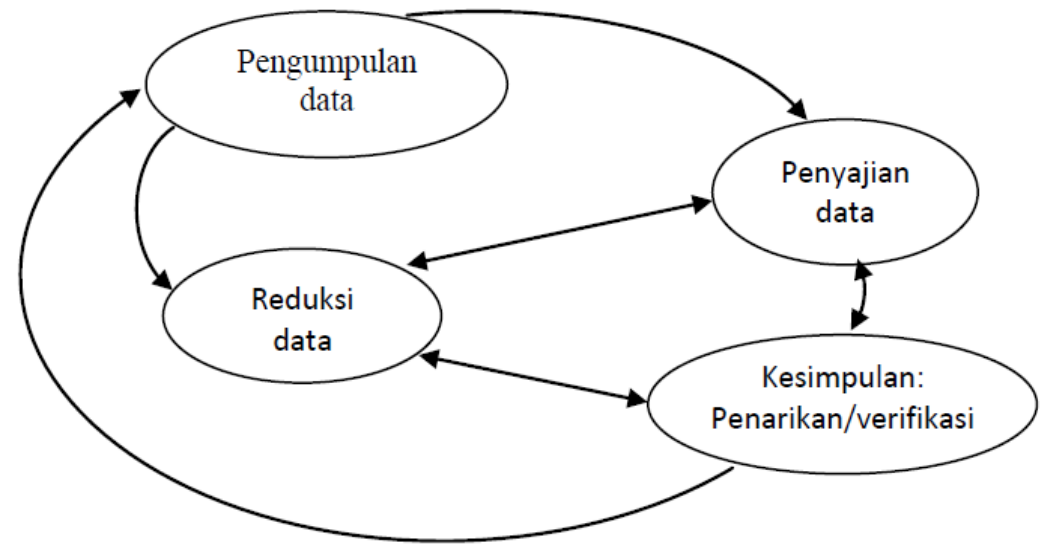

Bagan 3.1 Komponen-komponen Analisis Data (Miles dan Huberman, 2007: 20)

\section{GAMBARAN UMUM LOKASI PENELITIAN}

\section{Keadaan Geografi}

Keadaan Geografis merupakan suatu keadaan Desa atau daerah yang menggambarkan letak, bentang alam dan batas-batas wilayah suatu tempat tertentu. Adapun keadaan geografis Desa Mondoe dapat di deskripsikan sebagai berikut:

\section{- Luas Daerah}

Desa Mondoe merupakan salah satu Desa yang berada di Kecamatan Palangga Selatan Kabupaten Konawe Selatan Sulawesi Tenggara. Desa Mondoe memiliki luas wilayah \pm 1200 hektar, yang terdiri dari 4 Dusun dan satu dusun terbagi atas 2 RT serta masing-masing dusun terdiri atas beberapa Kepala Keluraga (KK)

$\checkmark$ Dusun I 33 KK

$\checkmark$ Dusun II $25 \mathrm{KK}$

$\checkmark$ Dusun III $30 \mathrm{KK}$

$\checkmark$ Dusun IV $23 \mathrm{KK}$
- Batas Wilayah

Desa Mondoe sebagai bagaian dari wilayah administrasi Kecamatan Palangga Selatan yang memiliki luas wilayah $1200 \mathrm{Km}^{2}$ memiliki batas wilayah sebagai berikut:

$\checkmark$ Sebelah Utara berbatasan dengan Desa Wawonua

$\checkmark$ Sebelah Timur berbatasan dengan Desa Torobulu

$\checkmark$ Sebelah Selatan berbatasan dengan Selat Tiworo Kabupaten MunaSebelah Barat berbatasan dengan Desa Parasi.

- Kondisi Geografis

Desa Mondoe Merupakan daerah perkebunan dengan sebagian besar wilayahnya merupakan sawah, tambang dan empang dan sebagaian besar wilayahnya tidak jauh dari daerah pesisir pantai.

- Kondisi Iklim 
Daerah Desa Mondoe memiliki ciri-ciri iklim yang sama dengan daerah lain di Sulawesi Tenggara yang umumnya beriklim Tropis dengan keadaan suhu berkisar $32^{\circ} \mathrm{C}$. Daerah ini memiliki 2 musim dalam setahun yaitu musim panas dan musim hujan. Musim hujan biasanya berlangsung dari bulan Desember sampai bulan Mei.

\section{HASIL DAN PEMBAHASAN}

a. Persepsi Masyarakat Tentang Adanya Penambangan Nikel dan Dampaknya Terhadap Lingkungan di Desa Mondoe Kecamatan Palangga Selatan

Hadirnya perusahaan pertambang an dalam setiap daerah yang memiliki potensi sumber daya alam adalah menjadi harapan oleh setiap masyarakat untuk peningkataan sumber daya ekonomi masyarakat.Namun demikian tidak semua semua wialayah yang memiliki sumber daya alam dapat memaksimalkan sumber daya alam yang ada diwilayahnya untuk dapat mensejahtrakaan masyarakatnya bahkan sebagian wilayah masyarakat hanya mendapatkan dampak negatif dari adanya aktivitas penambangan.Kondisi ini tentu saja dipengaruhi oleh berbagai macam faktor termasuk komitemen perusahaan dalam memberikan kesejahtraan ekonomi dan kemanfaataan kepada masyarakat yang ada dalam wilayah pertambangan.

Fakta di atas juga terjadi pada masyarakat Desa Mondoe Kecamatan Palangga Selatan. Berdasarkan data yang diperoleh dari angket penelitian maka pandangan masyarakat Desa Mondoe terhadap penambangan nikel di Desa Mondoe dan dampaknya terhadap lingkungan dapat dijabarkan melalaui indikator berikut:

- Pengetahuan Masyarakat dengan Adanya Pertambangan dapat Merusak Lingkungan

Pengetahuan seseorang sangat menentukan tentang sudut pandang yang diberikan pada keadaan suatu obyek sehingga dengan demikian pengetahuan berkontribusi besar dalam mempengaruhi sudut pandang responden. Pengetahuan yang baik yang dimiliki akan sejalan dengan sudut pandang yang baik dalam memandang suatu masalah. Adapun lebih jelasnya tentang pengetahuan responden tentang adanya pertambangan dapak merusak lingkungan dapat dilihat pada tabel berikut.

Tabel 4.1 Pengetahuan Masyarakat Tentang Adanya Pertambangan Dapat Merusak Lingkungan

\begin{tabular}{ccc}
\hline PENILAIAN & Frekuensi (F) & Persentase (P) \\
\hline Sangat Setuju & 6 & $20 \%$ \\
\hline Setuju & 24 & $80 \%$ \\
\hline Kurang Setuju & 0 & $0 \%$ \\
\hline Tidak Setuju & 0 & $0 \%$ \\
\hline Jumlah & $\mathbf{3 0}$ & $\mathbf{1 0 0 \%}$ \\
\hline
\end{tabular}

Sumber: Data Diolah (2018) 
- Pemahaman Masyarakat tentang Keberlangsungan Lingkungan Hidup yang Berkelanjutan Sangat Penting

$\begin{array}{lr}\text { Pemahaman masyarakat } \\ \text { sangat penting } & \text { terhadap } \\ \text { keberlangsungan suatu } & \text { lingkungan } \\ \text { yang berkelanjutan } & \text { dengan } \\ \text { pemanfaatan yang berwawasan } & \text { bangangan } \\ \text { lingkungan.Dalam } & \text { hubunganya } \\ \text { dengan pertambangan maka } & \text { pemahaman masyarakat yang baik }\end{array}$

akan mempengaruhi pandanganya pada dampak yang ditimbulkan perusahan sebagai akibat terhadap kebelangsungan lingkungan hidup tempat masyarakat hidup. Adapun lebih jelasnya tentang pemahaman masyarakat tentang keberlangsungan lingkungan hidup yang berkelanjutan dalam hubunganya dengan adanya pertambangan di Desa Mondoe dapat dilihat pada tabel berikut.

Tabel 4.2 Pemahaman Masyarakat Tentang Keberlangsungan Hidup Yang

Berkelanjutan

\begin{tabular}{ccc}
\hline PENILAIAN & Frekuensi (F) & Persentase (P) \\
\hline Sangat Setuju & 6 & $20 \%$ \\
\hline Setuju & 22 & $73.33 \%$ \\
\hline Kurang Setuju & 2 & $6.66 \%$ \\
\hline Tidak Setuju & 0 & $0 \%$ \\
\hline Jumlah & $\mathbf{3 0}$ & $\mathbf{1 0 0 \%}$ \\
\hline
\end{tabular}

\section{Sumber: Data Diolah (2018)}

- Kesadaran Masyarakat Terhadap Dampak yang Ditimbulkan oleh Perusahan Penambangan

Kesadaran masyarakat dalam memikirnya kondisi lingkungan untuk masa yang akan datang adalah bentuk wawasan yang berkelanjutan dari adanya pemahaman dan pengetahuan yang baik dari masyarakat tentang pentingnya lingkungan agar terhindar dari kerusakan dengan adanya perusahan pertambangan di Desa Mondoe. Adapun kesadaran masyarakat terhadap adanya dampak yang ditimbulkan oleh perusahan penambangan maka dapat dilihat pada tabel berikut:

Tabel 4.3 Kesadaran Masyarakat Terhadap Dampak yang Ditimbulkan Perusahan Pertambangan

\begin{tabular}{ccc}
\hline PENILAIAN & Frekuensi (F) & Persentase (P) \\
\hline Sangat Setuju & 8 & $26.66 \%$ \\
\hline Setuju & 20 & $66.66 \%$ \\
\hline Kurang Setuju & 2 & $6.66 \%$ \\
\hline Tidak Setuju & 0 & $0 \%$ \\
\hline Jumlah & $\mathbf{3 0}$ & $\mathbf{1 0 0 \%}$ \\
\hline
\end{tabular}

Sumber: Data Diolah (2018) 
Jurnal Penelitian Pendidikan Geografi Volume 4 Nomor 1 Januari 2019

\section{b. Dampak Penambangan Nikel Terhadap Kerusakan Fisik Lingkungan di Desa Mondoe Kecamatan Palangga Selatan}

Pertambangan pada dasarnya adalah upaya untuk mengelola sumber daya alam yang ada untuk dapat dipergunakan untuk peningkatan kesejahteraan masyarakat, namun demikian hadirnya sebuah perusahan pertambangan tidak saja hanya memberikan dampak positif tetapi sebaliknya juga menimbulkan dampak negatif salah satunya adalah kerusakan lingkungan fisik dan kerusakan pada alam lingkungan pada umumnya.Bentuk- bentuk kerusakan fisik lingkungan dapat dilihat dengan berbagai indikator yang mencakup kerusakan hutan, peningkatan polusi debu, bertambahnya lahan kritis, peningkatan Terjadinya longsor, kerusakan lahan, kerusakan jalan raya, dan pencemaran air bersih. Adapun lebih jelasnya tentang indikatorindikator kerusakan lingkungan fisik yang ditimbulkan perusahan tambang nikel di Desa Mondoe Kecamatan Palangga Selatan Kabupaten Konawe Selatan dapat dijabarkan berdasaarkan indikator-indikator variabel berikut:

- Kerusakan Lingkungan Hutan

Lingkungan hutan adalah area penghijauan yang sangat berkontribusi dalam menjaga keseimbangan ekosistim mahluk hidup yang ada dalam kawan hutan. Oleh karena itu adanya kawasan hutan sangat penting dalam menjaga kelangsungan semua mahluk hidup termasuk manusia.

- Peningkatan Polusi Udara

Setiap individu berhak
mendapatkan udara yang bersih
disekitarnya, namun demikian
adanya perusahaan tambang di Desa
Mondoe Kecamatan Palangga

Selatan maka menimbulkan masalah termsuk terjadinya peningkatan polusi udara sebagai dampak dari aktivitas penambanga nikel.

- Bertambanya Lahan Kritis

Kegiatan penambangan adalah proses penggalian dan pengektrakan material bahan tambang dari dalam bumi beruapa bahan galian. Oleh karena itu karena bahan tambang merupakan bahan galian maka tentu dapat menimbulkan lahan kritis dari bekas terjadinya penambangan.

- Penyebab Terjadinya Longsor

Aktifitas penambangan pada dasarnya selain melakukan pengerukan tanah yang ada dipermukaan tanah juga dilakukan pengerukan tanah yang ada dalam bumi. Selain itu dalam penambangan juga dilakukan pengambilan tanah yang ada didaerah lereng guunung atau perbukitan sehingga dapat menimbulkan longsor.

- Kerusakan Lahan

Kerusakan lahan juga menjadi salah satu aspek dari dampak adanya aktivitas pertambangan nikel di Desa Mondoe Kecamatan PalanggaSelatan.Lahan sebagai bagian yang dieksplorasi dan dieksploitasi sangat berpontesi besar untuk mengalami kerusakan dengan adanya aktivitas pertmbangan.

- Kerusakan Jalan Raya

Jalan raya adalah merupakan salah satu sarana fasilitas umum yang diperlukan masyarakat untuk menghubungkan satu daerah dengan daerah lainya. Adanya jalan raya maka dapat mempermudah masyarakat untuk mengakses kebutuhanya dari daerah lain. Kondisi ini menggambarkan bahwa jalan raya merupakan fasilitas umum yang 
Jurnal Penelitian Pendidikan Geografi Volume 4 Nomor 1 Januari 2019

diperlukan sangat penting olah masyaraat umum.

- Pencemaran Air Bersih

Air bersih adalah sumber kebutuhan pokok masyarakat untuk melangsungkan hidupnya.Oleh karena itu ketersedian air bersih bagi masyarakat adalah sebuah keniscayaan yang harus dipenuhi.Namun demikian kehadiran perusahan diwilayah Desa Mondoe mempengaruhi ketersedian air bersih di Desa Mondoe.

c. Upaya yang Dilakukan Masyarakat dan Pemerintah dalam Mengatasi Dampak Penambangan Nikel Terhadap Lingkungan yang terjadi di Desa Mondoe Kecamatan Palangga Selatan

Aktivitas penambangan selain memberikan dampak positif terhadap peningkatan ekonomi masyarakat, penyerapan tenaga kerja dan juga peningkatan pendapatan daerah juga memberikan dampak negatif terhadap kelangsungan wilayah dan lokasi penambangan. Oleh karena itu diperlukan upaya untuk meminimalisir dampak yang ditimbulkan oleh aktivitas penambangan agar kelestarian lingkungan tetap terjadi secara berkelanjutan.

Adapun upaya yang dilakukan dalam mengatasi dampak yang ditimbulkan penambangan nikel di Desa Mondoe Kecamatan PalanggaSelatan antara lain mencakup penekanan kepada perusahaan dan pemerintah untuk merehabitiasi lahan, penyiraman jalan raya saat musim panas untuk mengurangi polusi debu, perbaikan jalanan yang rusak. Untuk lebih jelasnya tentang upaya yang dilakukan masyarakat dan pemerintah Desa Mondoe dapat dijabarkan sebagai berikut:

- Merehabilitasi Lahan

Rehabilitasi lahan merupakan suatu usaha memperbaiki, memulihkan kembali dan meningkatkan kondisi lahan yang rusak agar dapat berfungsi secara optimal baik sebagai unsur produksi, media pengatur tata air, maupun sebagai unsur perlindungan alam dan lingkungannya. Adapun tanggapan masyarakat tentang rehabilitasi lahan yang diupayakan pemerintah dan masyarakat serta perusahan dapat dilihat pada tabel berikut:

Tabel 4.4 Tanggapan Masyarakat Tentang Upaya Rehabilitasi Lahan Kawasan Bekas Penambangan

\begin{tabular}{ccc}
\hline PENILAIAN & Frekuensi (F) & Persentase (P) \\
\hline Sangat Setuju & 10 & $33.33 \%$ \\
\hline Setuju & 15 & $50 \%$ \\
\hline Kurang Setuju & 5 & $16.66 \%$ \\
\hline Tidak Setuju & 0 & $0 \%$ \\
\hline Jumlah & $\mathbf{3 0}$ & $\mathbf{1 0 0 \%}$ \\
\hline
\end{tabular}

Sumber : Data Diolah (2018)

- Penyiraman Debu di Jalan Pada Musim Panas
Penyiraman jalan adalah salah upaya yang dilakukan oleh perusahaan 
maupun masyarakat secara rutin setiap hari untuk mengurangi polusi debu yang ditimbulkan oleh kendaraan mobil pengangkut material pertambangan yang tiap saat melewati jalan raya.Kondisi debu memang sangat memprihatinkan terutama rumah masyarakat yang berada diwilyah pinggir jalan sehingga dalam upaya meminimalisir debu yang ada dijalan raya terutama pada musim panas. Adapun tanggapan responden tentang upaya penyiraman debu di jalan raya pada musim panas dapat dilihat pada tabel berikut:

Tabel 4.5 Tanggapan Masyarakat Tentang Upaya Penyiraman Debu Jalan Sebagai Langkah Meminimalisir Dampak Polusi Udara

\begin{tabular}{ccc}
\hline PENILAIAN & Frekuensi (F) & Persentase (P) \\
\hline Sangat Setuju & 24 & $80 \%$ \\
\hline Setuju & 6 & $20 \%$ \\
\hline Kurang Setuju & 0 & $0 \%$ \\
\hline Tidak Setuju & 0 & $0 \%$ \\
\hline Jumlah & $\mathbf{3 0}$ & $\mathbf{1 0 0 \%}$ \\
\hline
\end{tabular}

Sumber: Data diolah (2018)

- Perbaikan Jalan Rusak

Jalan raya sebagai salah satu fasilitas publik yang sangat dibutuhkan masyarakat untuk memenuhi kebutuhan hidupnya dari wilayah lain tentu menjadi salah satu yang harus diperhatikan. Namun demikian dengan adanya kativitas penambangan di daerah Desa Mondoe jalan raya tidak terlepas dari dampak kerusakan dari aktifitas mobil pengangkut material tambang dari lokasi penambangan.Oleh karena itu maka perusahan memiliki tanggung jawab untuk melakukan perbaikan pada jalan yang rusak yang dilewati kendaraan perusahaan yang operasional. Adapun lebih jelasnya tentang tanggapan responden mengenai pentingnya perbaikan jalan yang rusak sebagai salah satu dampak yang ditimbulkan oleh aktivitas penambangan dapat dilihat pada tabel berikut.

Tabel 4.6 Tanggapan Masyarakat Tentang Pentingnya Perbaikan Jalan yang Rusak dilakukan oleh Perusahaan

\begin{tabular}{ccc}
\hline PENILAIAN & Frekuensi (F) & Persentase (P) \\
\hline Sangat Setuju & 20 & $66.66 \%$ \\
\hline Setuju & 10 & $33.33 \%$ \\
\hline Kurang Setuju & 0 & $0 \%$ \\
\hline Tidak Setuju & 0 & $0 \%$ \\
\hline Jumlah & $\mathbf{3 0}$ & $\mathbf{1 0 0 \%}$ \\
\hline
\end{tabular}

\section{Sumber: Data Diolah (2018)}


- Reboisasi Hutan dengan Penghijauan Reboisasi adalah upaya penghijauan yang dilakukan pada lahan yang sudah tandus yang melibatkan kesadaran masyarakat untuk memulihkan kembali tentang resapan tanah sehingga dapat memperbaiki lahan dan menjaga ketersedian air tanah. Disisi lainadanya reboisasi dapat mencegah terjadinya tanah longsor karena dengan penghijauan dapat memperkuat kembali ikatan tanah yang telah tandus. Adapun tanggapan responden tentang reboisasi hutan dengan penghijauan dapat dilihat pada tabel berikut:

Tabel 4.7 Tanggapan Masyarakat Tentang Pentingnya Reboisasi Hutan dengan Penghijauan

\begin{tabular}{ccc}
\hline PENILAIAN & Frekuensi (F) & Persentase (P) \\
\hline Sangat Setuju & 20 & $66.66 \%$ \\
\hline Setuju & 10 & $33.33 \%$ \\
\hline Kurang Setuju & 0 & $0 \%$ \\
\hline Tidak Setuju & 0 & $0 \%$ \\
\hline Jumlah & $\mathbf{3 0}$ & $\mathbf{1 0 0 \%}$ \\
\hline
\end{tabular}

\section{Sumber: Data Diolah (2018)}

\section{d. Implikasi Penelitian Terhadap Perkembangan Pendidikan Geografi di SMA}

Ilmu pengetahuan akan terus berkembang ketika manusia sebagai subyek dari pengembangan ilmu pengetahuan terus berupaya dalam melakukan penelitian dan pengakajian tentang hal-hal yang baru yang berhubungan dengan keilmuanya.

Sebagaimana dalam penelitian ini diharapkan memberikan implikasi terhadap pengembangan ilmu pengetahuan geografi khusunya mata pelajaran Geografi di SMA.

Ruang lingkup ilmu geografi dikenal adanya geografi regional merupakan deskripsi yang menyeluruh antara aspek manusia dan aspek alam (lingkungan). Fokus kajiannya adalah interelasi, interaksi dan integrasi antara aspek alam dan manusia dalam suatu ruang tertentu. Walaupun geografi fisik mengkaji aspek fisik, tetapi selalu mengkaitkannya dengan aspek manusia dalam suatu "ruang". Dalam tataran sistematika sebagaimana uraian di atas, geografi lingkungan merupakan bagian dari geografi regional,karena dalam perspektif bidang ini memberi tekanan pada hubungan antara manusia dengan lingkungannya sehingga terlihat karakteristk lingkungan di wilayah tersebut.

Selanjutnya geografi juga merupakan ilmu yang bersifat antroposentris, melihat manusia secara dua sisi yaitu manusia mempunyai tanggungjawab yang lebih dibandingkan makhluk hidup lainnya, dalam memanfaatkan alam selalu ada resiko-resiko terhadap alam, karena itu tanggungjawab, etika lingkungan harus selalu dilibatkan dalam memanfaatkan lingkungan. Pada materi Geografi kelas XI SMA kurikulum 
2013 sendiri membahas mengenai pertambangan sehingga melaluipenelitian ini dapat berkontribusi positif terhadap pengembangan materi-materi pendidikan geografi khususnya tentang masalah yang berhubungan dengan pertambangan berupa materi pokok persebaran barang tambang di Indonesia agar dapat menambah teoritis tentang masalah penambangan sehingga siswa dapat memperoleh bekal pengetahuan dasar tentang sumber daya tambang yang tersebar di Indonesia yang harus dikelola dan dimanfaatkan dengan baik tanpa harus merusak lingkungan yang ada.

\section{KESIMPULAN}

Berdasarkan hasil penelitian dan pembahasan dalam penelitian ini maka penulis menyimpulkan beberapa kesimpulan sebagai berikut:

- Pandangan masyarakat Desa Mondoe terhadap keberadaan perusahan penambangan nikel menganggap menimbulkan kerusakan terhadap lingkungan secara fisik.

- Bentuk-bentuk kerusakan lingkungan fisik yang ditimbulkan dari adanya perusahan penambangan nikel di Desa Mondoe Kecamatan Palangga Selatan mencakup kerusakan lingkungan hutan, peningkatan polusi udara, bertambahnya lahan kritis, penyebab terjadinya longsor, kerusakan lahan,kerusakan jalan raya dan pencemaran air bersih.

- Upaya yang dilakukan pemerintah dan masyarakat Desa Mondoe dalam meminimalisir dampak yang ditimbulkan dari aktivitas penambangan yang merusak lingkungan mencakup rehabilitas lahan, penyirman jalan untuk mengurangi polusi debu secara berkala dan perbaikan jalanan yang rusak oleh pemerintah dan perusahan sebagai bentuk tanggung jawab.

\section{DAFTAR PUSTAKA}

Abrar Saleng. 2004. Hukum Pertambangan, UII Press Yogyakarta

Alex Sobur. 2009. Psikologi Umum. Bandung: UPI University Pers

Abdulsyani. 2007. Sosiologi, Skematika, Teori, Dan Terapan. Jakarta: PT.Bumi Aksara

Arikunto, Suharsini. 1997. Prosedur Penelitian Suatu Pendekatan Praktek. Jakarta: Rineka Cipta.

Bimo, Walgito. 2002. Pengantar Psikologi Umum. Yogyakarta: Andi Offset

Creswell, J. W. 2010. Research Desaign (pendekatan kualitatif, kuantitatif, dan mixed). Yogyakarta: Pustaka Pelajar.

Danusaputro, Munadjat. 1982. Hukum Lingkungan, Buku IV, Global, Binacipta, Bandung.

Elsam. 2003. Perjuangan Amungme Antara Freeport dan Militer. Insist Press : Yogyakarta

Gillin, J. L. dan J.P. Gillin. 1954. For A Science of Social Man. New Yor: McMillan. 
Jurnal Penelitian Pendidikan Geografi Volume 4 Nomor 1 Januari 2019

Hadi, Sudharto P., 2005. Aspek Sosial Amdal. Yogyakarta: Gadjah Mada University Press.

Hayati, Sri. 2003. Pendekatan Joyful Learning Dalam Pembelajaran Pendidikan Lingkungan Hidup. Buletin Pelangi Pendidikan (Buletin Peningkatan Mutu Pendidikan SLTP), Volume 6 No. 1 Tahun 2003.

Irwanto. 2002. Psikologi Umum, (Buku PANDUAN mahasiswa), Jakarta: PT. Prehallindo.

Koentjaraningrat (ed.), 1980c. Metodemetode Penelitian Masyarakat. Jakarta: Gramedia

M.Husein, Harum. 1995. Lingkungan Hidup Masalah Pengelolaan Dan Penegakan Hukumnya, Jakarta: Bumi Angkasa.

Mar'at, 1991. Sikap Manusia Perubahan Serta Pengukurannya. Jakarta: Ghalia Indonesia

Miles dan Huberman.2007. Analisis Data Kualitatif; Buku sumber tentang Metode-Metode Baru. Jakarta, Universitas Indonesia Press.

Rahmat, Jalaluddin. 2004. Psikologi Komunikasi. Bandung: Remaja Rosdakarya.

Roucek, S.J dan Warren, L.R, 1984. Pengantar Sosiologi Jakarta: Bina Aksara.
Salim HS. 2004. Hukum Pertambangan di Indonesia. Jakarta: PT. Raja Grafindo Persada.

Salim, Emil. 1982. Lingkungan Hidup dan Pembangunan. Jakarta: Mutiara. 